\title{
Método de análisis para determinar el contenido de humedad adecuado para la obtención de resistencias en fachadas trasventiladas de piedra natural sometidas al agua de lluvia
}

\author{
Natural stone in ventilated façades: \\ method for determining \\ the appropriate moisture content for strength tests
}

\author{
$\underline{\text { C. Vielba }}^{(*)}$
}

Recepción/Received: 25-IV-07

Aceptación/Accepted: 5-XII-07

Publicado online/Online publishing: 26-II-09

\section{RESUMEN}

El artículo muestra la influencia que tiene la consideración del contenido de humedad en el diseño de las fachadas trasventiladas hechas de piedra natural porosa. Se comprueba cómo este factor influye en la resistencia de las placas y condiciona sus dimensiones. Por ello se propone realizar un análisis más amplio del comportamiento frente al agua, que el propuesto por las normas EN. A través de un ejemplo, se muestra cómo realizar dicho análisis y se dan pautas para elegir un contenido de humedad que represente el grado de absorción que la piedra pueda alcanzar en este tipo de fachadas. Con este contenido, se determinarán las resistencias mecánicas de las placas. El estudio se ha aplicado a tres areniscas de la misma zona del noreste español, obteniendo resultados que demuestran la utilidad del análisis que se propone.

Palabras clave: piedra natural, arenisca, humedad, absorción, fachadas trasventiladas, resistencia a flexión.

\section{SUMMARY}

The article discusses the effect of the assumptions about moisture content on the design of ventilated façades with porous natural stone cladding. Moisture is shown to impact cladding strength and condition its dimensions. For this reason the performance of such façades when exposed to water should be analyzed more fully than specified in EN standards. An example is given of how to conduct such an analysis, along with guidelines for choosing a moisture content value that correctly reflects the absorption levels attainable in such façades. This value is then used to determine panel mechanical strength. Application of the method to three sandstones from Northeastern Spain showed the utility of the type of analysis proposed.

Keywords: natural stone, sandstone, moisture, absorption, ventilated façades, flexural strength.

(*) Universidad Politécnica de Madrid. 


\section{INTRODUCCIÓN}

Las fachadas trasventiladas son una de las aplicaciones más importantes que tiene la piedra natural. La definición constructiva de estos sistemas parte de establecer los valores geométricos de las placas a utilizar, basándose en los ensayos de determinación de resistencias. En la actualidad las normas EN, en base a las que se realiza el marcado CE de las placas (1-2), usan probetas secas para dicha determinación. Ello es adecuado para rocas de baja porosidad accesible, ya que, en este caso, la absorción que se puede alcanzar en una fachada trasventilada es baja, y los tiempos de secado son cortos. Sin embargo, en el caso de rocas porosas, como ciertas calizas y areniscas, puede ser arriesgado despreciar la influencia de la humectación en la resistencia.

En obras concretas, con una ubicación geográfica específica, un estudio detallado que tenga en cuenta la climatología de la zona permitiría determinar la humedad que una piedra podría alcanzar en una fachada. Sin embargo, si queremos realizar un análisis general, que aporte datos previos de utilidad para cualquier tipo de ubicación, es preciso establecer un contenido de humedad de referencia, que pueda servir como primera aproximación para contrastar el comportamiento de la piedra en seco y en húmedo.

En un artículo anterior (3) ya propusimos una sistemática de ensayos para determinar el comportamiento de las rocas porosas frente al agua. Aquí vamos a proponer un método para elegir el contenido de humedad de referencia con el que realizar los ensayos comparativos de resistencia, aplicándolo a la determinación de la resistencia a flexión. Para ello se han elegido tres piedras de características diferentes, pero procedentes de una misma zona geográfica: Lérida. Se trata de las areniscas cuarcíticas Gris Barcelona y Juneda y la arenisca Parisina, que han sido suministradas por Germans Balagué S.L. Todas ellas están compuestas de granos de cuarzo cementados mayoritariamente por carbonato cálcico.

Las fases del estudio que hemos realizado son:

1. Análisis del comportamiento frente al agua de las tres piedras.

2. Determinación del contenido de humedad para la realización de los ensayos de resistencia.

3. Aplicación de los valores obtenidos a la realización de ensayos de resistencia a flexión.

4. Conclusiones.

\section{INTRODUCTION}

Cladding on ventilated façades is one of the most important uses of natural stone. The first step in designing these systems is to establish panel geometry based on strength tests. The present EN standards, on which the CE mark for cladding (1-2) is based, use dry specimens for such tests. This is appropriate for rocks with low values of porosity accessible to water, for the absorption levels attainable in such cladding are low and drying times are short. But risk may be incurred if the effect of moisture on strength is disregarded in porous rock such as limestone and sandstone.

For particular projects in a specific location, the amount of moisture that a façade stone can reach may be determined through a detailed study designed for the area's climate. Useful and generally applicable information can only be obtained, however, if the analysis conducted establishes a reference moisture value for use as a rough estimate to compare dry and wet stone behaviour.

An earlier article (3) proposed a system of tests for determining porous stone behaviour when exposed to water. The present paper proposes a method for choosing a reference moisture content with which to conduct comparative strength tests, which has been applied to determine stone panel flexural strength. Three stones with different characteristics but quarried in the same geographic area (the Spanish province of Lleida) were chosen for the survey. Two, Gris Barcelona and Juneda, were quartzitic sandstones and one, Parisina, a sandstone. All three were furnished by Germans Balagué S.L. and comprised quartz grains bonded primarily by a calcite cement.

The study was divided into several stages, namely:

1. Analysis of stone behaviour when exposed to water.

2. Determination of the moisture content for strength test purposes.

3. Application of the values obtained to conduct flexural strength tests.

4. Conclusions. 


\section{COMPORTAMIENTO FRENTE AL AGUA DE LAS PIEDRAS ANALIZADAS}

En el estudio se han tenido en cuenta las posibles formas de exposición al agua de la piedra en una fachada trasventilada que pueden resumirse en:

- Contacto simple con el agua de lluvia.

- Contacto con el agua de lluvia más presión de viento.

- Exposición a la humedad ambiental.

Para determinar la absorción en cada supuesto se ha procurado seguir ensayos EN, caso de existir ensayos aplicables o que puedan ser adaptados a la medición que se pretende realizar.

En el caso de contacto simple con agua de lluvia se ha tomado como referencia la norma UNE-EN 1925 (4), aunque nuestro objetivo no es obtener el coeficiente de absorción por capilaridad, sino elaborar gráficas absorción-tiempo, observando el avance del frente húmedo para determinar cuándo alcanza el agua la cara superior de la probeta y la cubre por completo.

La absorción en un aplacado sometido al agua de lluvia con presión de viento, se puede medir directamente aplicando sobre la probeta, con un dispositivo especial (3), una columna de agua que represente esa presión. Sin embargo tal ensayo no se encuentra contemplado en las normas EN para piedra natural. Además, en un estudio no condicionado a una ubicación geográfica concreta, no contamos con datos meteorológicos que permitan establecer una presión de viento de referencia. Como lo que nos interesa es comparar el comportamiento de la piedra en distintas situaciones de exposición al agua, podemos usar el ensayo por inmersión UNE-EN 13755 (5), midiendo no sólo valores globales, sino elaborando también las gráficas absorción-tiempo.

Para la exposición a la humedad ambiental no existe norma de referencia, así que se ha optado por reproducir una situación climatológica extrema, introduciendo las probetas en un armario húmedo $\left(\mathrm{HR}=95 \%\right.$ y $\left.22{ }^{\circ} \mathrm{C}\right)$ y determinando las curvas adsorción-tiempo.

\section{Ensayo a succión}

\section{Consideraciones previas}

El comportamiento de la piedra a succión se puede relacionar con el que tendría en una fachada sometida a la lluvia sin presión de viento. En ese caso el agua, al resbalar por la pared, va penetrando gradualmente por capilaridad.

Siguiendo la norma UNE-EN 1925 (4) se han utilizado 6 probetas cúbicas de $50 \pm 5 \mathrm{~mm}$ de lado. El dispositivo utilizado

\section{BEHAVIOUR OF THE STONE ANALYZED WHEN EXPOSED TO WATER}

The study covered the various types of exposure to water that may affect stone on a ventilated façade, i.e.:

- Simple contact with rainwater

- Contact with wind-driven rainwater

- Exposure to moisture in the air

Where possible, absorption was determined under each of the above conditions using or adapting European EN standard trials to the parameter to be measured.

For contact with rainwater, the reference used was Spanish and European standard UNE-EN 1925 (4), although the aim was not to find the capillary absorption coefficient, but to formulate absorption-time graphs to monitor the advance of the moisture front and determine when the water reached and completely moistened the top of the specimen.

Absorption by panels exposed to wind-driven rainwater can be measured directly with a special device (3) that applies a water column to the specimen to simulate wind pressure. That test is not set out in the EN standards for natural stone, however. Moreover, a study unconditioned by a specific geographic location lacks meteorological data with which to establish a standard wind pressure. To compare stone behaviour under different moisture conditions, which was the aim here, the UNEEN 13755 (5) immersion test can be used if in addition to measuring overall values, absorption-time graphs are plotted.

No standard describes a test to measure exposure to the moisture in the air. Here, the solution applied was to reproduce extreme weather conditions by placing the specimens in a humidity chamber $\left(H R=95 \%, 22{ }^{\circ} \mathrm{C}\right)$ and plotting the respective adsorption-time curves.

\section{Suction test}

\section{Prior considerations}

The behaviour of a façade exposed to windless rain can be likened to the suction behaviour of the constituent stone. In this case, the water sliding down the wall gradually penetrates the stone due to capillary action.

Further to UNE-EN standard 1925 (4), six 50 5 -mm cubic specimens were prepared. The apparatus used was 
es un recipiente con unas esferas de vidrio en su fondo sobre las que descansan las probetas, de modo que la mayor parte de su superficie inferior se encuentra en contacto directo con el agua (Figura 1). a receptacle with glass beads on the bottom on which the specimens were set to ensure that most of the bottom surface was in direct contact with the water (Figure 1).

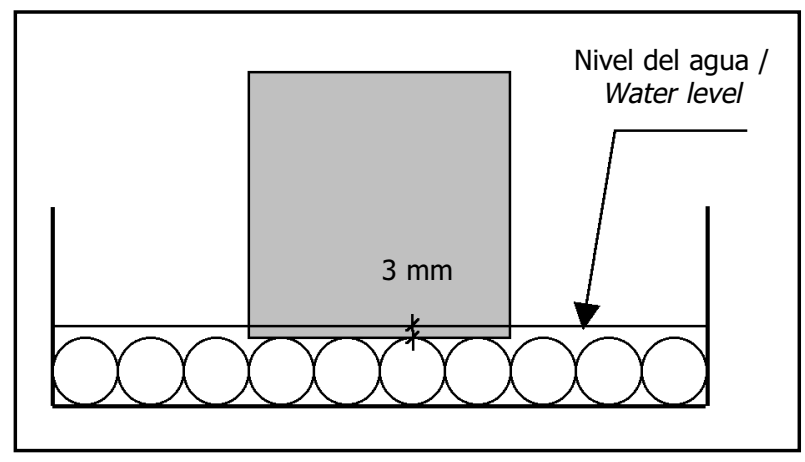

Figura 1. Ensayo a succión.

Figure 1. Suction test.

Sin embargo, antes de realizar el ensayo hay dos factores que deben considerarse:

1. Las rocas sedimentarias presentan anisotropías que pueden influir en los ensayos, obligando a considerar por separado las distintas direcciones de avance del agua. Por ello, en una fase previa, se ha ensayado cada probeta en sus tres direcciones, comparando las curvas absorción-tiempo para detectar diferencias de comportamiento. Sólo dos muestras de la arenisca Juneda presentaron ligeras desviaciones en la fase inicial. En el resto el comportamiento ha sido similar en las tres direcciones. Por ello se ha decidido considerar sólo una dirección, al azar, en los ensayos definitivos.

2. Las areniscas presentan una porosidad muy irregular, con una red primaria, que corresponde fundamentalmente a los capilares de la matriz, y una red secundaria constituida por pequeñas cavidades interconectadas por un sistema de microfisuras. Se supone que el agua absorbida, fluye fundamentalmente por la red secundaria, con una velocidad que depende del volumen de cavidades y del grado de conexión entre ellas (6). La irregularidad de esta red hace que el comportamiento de la piedra no sea homogéneo.

Utilizando probetas de igual espesor pero distinta superficie, se ha detectado que, con mayor superficie expuesta al agua, el tiempo hasta la total humectación de la cara superior se alarga. Ello se debe a que hay pequeñas áreas que tardan en cubrirse, seguramente por presentar menor interconexión entre cavidades. Sin embargo, las curvas de absorción tienen la misma forma, independientemente del tamaño de probeta, y presentan los mismos puntos singulares. Por ello se ha decidido usar probetas cúbicas de $50 \mathrm{~mm}$ de lado, de acuerdo con UNE-EN 1925 (4), centrando el estudio en
Before proceeding to the test, however, two factors had to be considered:

1. Sedimentary rocks exhibit anisotropies that may affect test results. Consequently, each specimen was preliminarily tested in all three directions and the resulting absorption-time curves were compared to detect behavioural differences. Only two Juneda sandstone samples exhibited slight deviations in this initial phase. In all the other specimens, behaviour was similar in the three directions. The final tests were conducted, then, in one direction only, chosen at random.

2. Porosity is highly irregular in sandstones, whose primary network consists essentially in capillary pores in the matrix while its secondary network comprises small cavities or vugs interconnected by a system of microfissures. Water is assumed to flow primarily through the secondary network at a rate that depends on vug volume and interconnectivity (6). Due to the irregularities in such networks, stone behaviour is not uniform.

Using specimens with the same thickness but different surface characteristics showed that the greater the area exposed to water, the longer it took to soak the entire top side. This is due to the existence of small regions where moistening is delayed, very likely due to less intense vug interconnectivity. The absorption curves had the same shape, however, regardless of specimen size and exhibited the same singular points. This led to the decision to use 50-mm cubic specimens, as specified in UNE-EN 1925 (4), focusing on obtaining the 
la obtención de los valores singulares de absorción y tomando los tiempos sólo como referencia.

\section{Resultado del ensayo}

- En la arenisca Gris Barcelona la succión es lenta y muy baja, no habiendo sido capaz el agua de atravesar la probeta tras 24 horas de ensayo.

- En la arenisca Parisina la succión es lenta y muy alta, tardando el agua una media de 75 minutos en empapar completamente la cara superior de las probetas ensayadas.

- La arenisca Juneda presenta una succión intermedia. La primera fase del proceso es muy rápida: a los 10 minutos el agua ha empapado completamente la cara superior. A partir de ese momento la absorción crece de forma lentísima.

Los resultados se recogen en la Tabla 1 y pueden verse representados gráficamente en la Figura 2. En la tabla en negrita y en la gráfica con un marcador de punto especial, se indica la absorción correspondiente al instante en el que la humedad invade totalmente la cara superior. singular absorption values and using the times for reference only.

\section{Test results}

- Suction-mediated absorption was low in the Gris Barcelona sandstone and took place slowly; the water failed to reach the top of the specimen after 24 hours.

- Suction water uptake was also small in the Parisina sandstone, although the absorption rate was very high; it took an average of 75 minutes to completely soak the top of the specimens.

- Suction in Juneda showed an intermediate suction value. And while the first phase was very rapid, with water completely soaking the top in ten minutes, absorption proceeded very slowly from then onward.

The results are given in Table 1 and plotted in Figure 2. The times at which specimen soaking was culminated, with completely moistening on the top side, are shown in bold on the table and as large dots on the figure.

Tabla 1 / Table 1

Succión de las tres areniscas.

Suction of the three sandstones.

\begin{tabular}{|c|c|c|c|}
\hline \multirow{2}{*}{$\begin{array}{c}\text { Tiempo / } \\
\text { (Time) }\end{array}$} & \multicolumn{3}{|c|}{ Absorción por succión (\%) / Absorption by suction (\%) } \\
\cline { 2 - 4 } & Gris Barcelona & Juneda & Parisina \\
\hline Minutos / minutes & \multicolumn{4}{|c|}{} \\
\hline 0 & 0 & 0 & 0 \\
\hline 5 & 0,09 & 3,80 & 2,76 \\
\hline 10 & 0,15 & $\mathbf{4 , 7 2}$ & 3,59 \\
\hline 15 & 0,18 & 4,77 & 4,31 \\
\hline 25 & 0,22 & 4,79 & 5,30 \\
\hline 35 & 0,26 & 4,80 & 6,14 \\
\hline 45 & 0,31 & 4,83 & 6,97 \\
\hline 60 & 0,34 & 4,84 & 7,86 \\
\hline 75 & - & - & $\mathbf{8 , 4 4}$ \\
\hline 90 & 0,41 & - & 8,61 \\
\hline Horas / hours & & & - \\
\hline 2 & 0,49 & - & - \\
\hline 3 & 0,60 & - & - \\
\hline 4 & 0,65 & - & - \\
\hline 6 & 0,73 & - & - \\
\hline 9 & 0,80 & - & - \\
\hline 24 & 0,94 & - & \\
\hline
\end{tabular}

En la arenisca Gris Barcelona no se ha alcanzado este punto y el proceso de succión se hace más lento a medida que transcurre el ensayo. La curva pasa de una pendiente del $1,8 \%$ a los 5 minutos, a pendiente inferior al $0,1 \%$ a las 24 horas. Por esa razón se decidió dar por terminado el ensayo sin que el agua alcanzase la cara opuesta.
That point was not reached in Gris Barcelona sandstone, whose suction rate slowed as the test progressed. The slope of the curve declined from $1,8 \%$ in the first five minutes to less than $0,1 \%$ after 24 hours. Consequent$l y$, the test was concluded before the water reached the top of the specimen. 


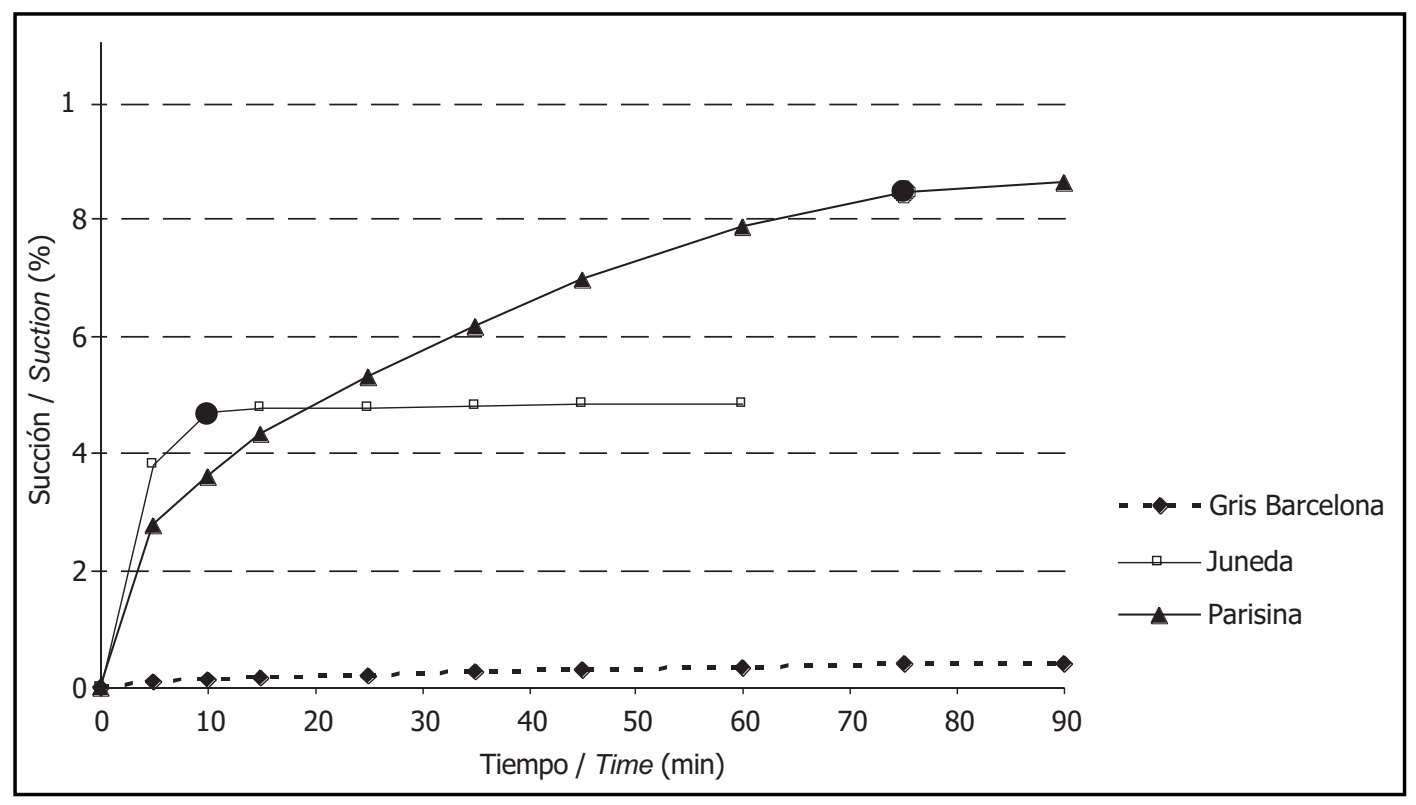

Figura 2. Absorción media por succión de los tres tipos de piedras. Figure 2. Mean value of absorption by suction of the three stones.

En la arenisca Juneda el agua invade la cara superior en 10 minutos. Hasta ese instante, la succión crece muy rápidamente y luego se mantiene en un crecimiento casi asintótico. La pendiente de la curva pasa del $76 \%$ a los 5 minutos al $18 \%$ a los 10 minutos y de ahí al $1 \%$ a los 15 minutos, manteniéndose, en las siguientes mediciones, siempre por debajo del $0,5 \%$.

El proceso es más lento en la arenisca Parisina. El agua tarda 75 minutos en invadir la cara superior y lo hace de forma gradual. La pendiente de la curva pasa, de forma suave, del $55 \%$ a los 5 minutos, al $4 \%$ a los 60 minutos. Al igual que ocurre con la arenisca Juneda, a partir del instante en el que la cara superior se moja completamente la pendiente desciende bruscamente.

Como vemos, el instante en el que el agua empapa la cara superior de las probetas es un hito importante en las areniscas Juneda y Parisina. Además los tiempos medidos en el ensayo son suficientemente cortos como para pensar que, en caso de chaparrones intensos o lluvias persistentes, las placas de un fachada trasventilada puedan alcanzar esta humedad.

El ensayo realizado ha aportado suficiente información para afrontar las siguientes fases del estudio y es muy sencillo de realizar. En casos en los que no se obtuviesen resultados tan claros, podría ser útil valorar previamente la anisotropía del material (7), para analizar a continuación la influencia de este factor en el proceso de succión.
In Juneda sandstone, the water rose to the top within 10 minutes. Suction progressed very rapidly up to that time, although the curve flattened visibly thereafter. After five minutes the slope was $76 \%, 18 \%$ after ten and $1 \%$ after fifteen. In subsequent measurements, it was consistently below $0,5 \%$.

The process was slower in Parisina sandstone. The water rose more gradually, reaching the top in 75 minutes. The slope of the curve also declined gradually, from 55\% after five minutes to $4 \%$ after sixty. As in the case of Juneda sandstone, however, the slope declined sharply after the top was completely moistened.

These findings show that the point when the specimens reach full saturation is an important milestone in Juneda and Parisina sandstone. Moreover, the times measured in the test were short enough to assume that, in the event of heavy or persistent rain, the cladding on a ventilated façade could reach the degree of moisture recorded.

The test, which is fairly easy to run, furnished sufficient information to undertake the following stages of the study. Where the results obtained are less clear, it may be useful to first test the material for anisotropy (7) and then analyze its effect on the suction process. 


\section{Ensayo de absorción por inmersión}

\section{Consideraciones previas}

Aunque el ensayo a inmersión no representa exactamente la exposición de una fachada ventilada ante una combinación de lluvia y viento, nos permite comprobar cómo se comportan las tres piedras cuando se añade una presión al contacto con el agua, y comparar resultados.

\section{Resultado del ensayo}

Los resultados del ensayo se pueden ver en la Tabla 2. Asimismo la Figura 3 muestra la curva de absorción correspondiente a las primeras 48 horas de ensayo. En la Tabla en negrita y en la Gráfica con un marcador de punto especial, se indica la absorción correspondiente al instante en el que se detecta un cambio importante de pendiente en la curva.

\section{Immersion tests}

\section{Prior considerations}

Although immersion does not exactly reproduce the exposure of a ventilated façade to a combination of wind and rain, it does give a sufficient indication of how the three stones behave when in contact with water under pressure to compare the results.

\section{Test results}

The results are given in Table 2. Figure 3, in turn, shows the absorption curve for the first 48 hours. The times when a substantial change was recorded in the slope of the curve are shown in bold on the table and as large dots on the figure.

Tabla 2 / Table 2

Absorción por inmersión de las tres areniscas.

Absorption by immersion of the three sandstones.

\begin{tabular}{|c|c|c|c|}
\hline \multirow{2}{*}{$\begin{array}{c}\text { Tiempo / } \\
\text { (Time) }\end{array}$} & \multicolumn{3}{|c|}{ Absorción por inmersión (\%) / Absorption by immersion (\%) } \\
\cline { 2 - 4 } & Gris Barcelona & Juneda & Parisina \\
\hline Minutos / minutes & \multicolumn{3}{|c|}{} \\
\hline 0 & 0 & 0 & 0 \\
\hline 60 & 0,79 & $\mathbf{4 , 7 5}$ & $\mathbf{8 , 6 6}$ \\
\hline 120 & 1,18 & 4,79 & 8,69 \\
\hline 180 & $\mathbf{1 , 4 2}$ & 4,80 & 8,71 \\
\hline \multicolumn{5}{|l}{} \\
\hline Horas / hours & 1,66 & 5,12 & 8,87 \\
\hline 24 & 1,69 & 5,17 & 9,06 \\
\hline 48 & 1,75 & 5,40 & 9,65 \\
\hline Días / days & 1,79 & 5,65 & 10,07 \\
\hline 7 & 1,83 & 5,78 & 10,31 \\
\hline 14 &
\end{tabular}

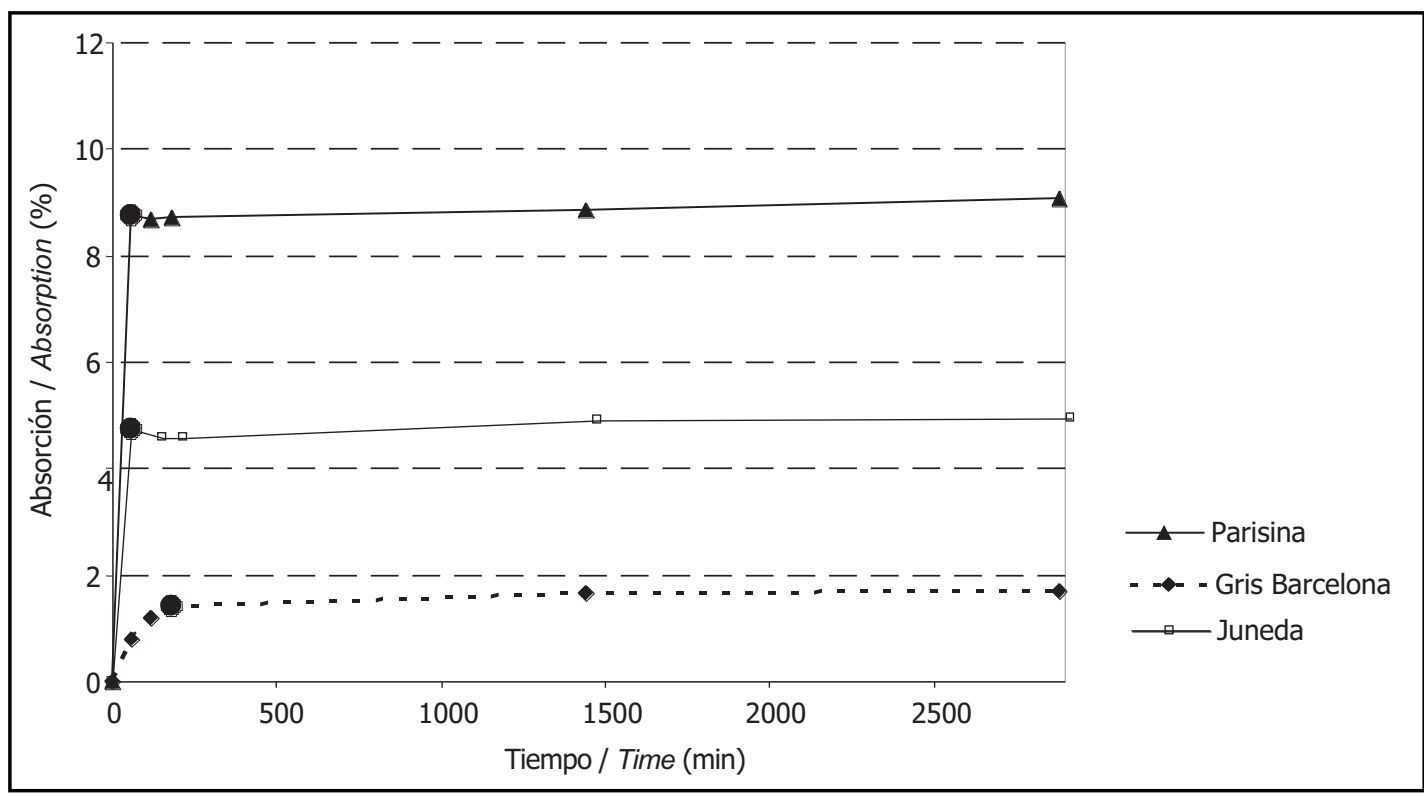

Figura 3. Absorción media por inmersión de los tres tipos de piedras. Figure 3. Mean absorption of the three stones (immersion). 
- En la arenisca Parisina la absorción es muy alta $(10,31 \%$ a 21 días) y crece rápidamente en los primeros instantes. En la primera medición, realizada conforme al ensayo normalizado, a los 60 minutos se llega a un $84 \%$ de la absorción total a 21 días. A partir de ahí la curva presenta una pendiente de crecimiento muy suave, siempre por debajo del $0,1 \%$.

- La arenisca Juneda presenta una gráfica similar a la Parisina pero con valores de absorción inferiores (5,78\% a 21 días, aproximadamente la mitad de la absorción de la arenisca Parisina). En la primera medición, a los 60 minutos, se llega a un $82 \%$ de la absorción total a 21 días, presentando la curva, a partir de ahí, un crecimiento lento con pendientes en descenso y siempre por debajo del $0,1 \%$.

- En la arenisca Gris Barcelona el proceso es más lento que en las otras dos piedras. Durante las primeras horas la absorción crece gradualmente pasando la pendiente de la curva del $1,32 \%$ a los 60 minutos al $0,4 \%$ a las tres horas, instante en el que se llega a un $78 \%$ de la absorción total a 21 días. A partir de ese momento, el crecimiento es casi horizontal con pendientes siempre inferiores al 0,1\%. La absorción total a 21 días es baja $(1,83 \%)$.

\section{Comparación de los resultados obtenidos en los ensayos de succión e inmersión}

Para tener más datos, para elegir el contenido de humedad adecuado para la realización de los ensayos de resistencia, hemos comparado, en cada piedra, las curvas de absorción por succión e inmersión. Aunque en ellos se han realizado mediciones en distintos tiempos, podemos combinar los valores obtenidos y representar las curvas de ambos en una misma gráfica.

En las areniscas Juneda y Parisina se ve cómo las gráficas de los primeros 180 minutos de ensayo se complementan, coincidiendo los valores de absorción de los puntos singulares: completa humectación de la cara superior por succión y punto de cambio brusco de pendiente en la curva del ensayo a inmersión (Figs. 4 y 5). Esos puntos pueden identificarse con el momento en el que la red porosa secundaria se colmata. A partir de ahí la absorción progresa muy lentamente, a medida que el agua avanza por los capilares más finos, siguiendo un crecimiento casi asintótico.

En la arenisca Juneda, que presenta una primera fase de absorción muy rápida, la red secundaria se ha llenado por succión en 10 minutos. Por inmersión, aunque se han realizado mediciones, de acuerdo con la norma, a partir del minuto 60 , se ha hecho un ensayo complementario, a tiempo inferior, comprobando que la red secundaria se colmata en 5 minutos.
- Absorption was very high (10,31\% after 21 days) and grew very quickly in the first few minutes. The value of the first reading, taken at $t=60$ minutes in accordance with the standardized test, was 84 $\%$ of the total 21-day absorption. Thereafter, the curve sloped very gently upward at a rate of under $0,1 \%$.

- The Juneda sandstone graph followed a similar pattern, but with lower absorption values (5,78\% after 21 days, approximately half of the Parisina rate). The first 60-minute value accounted for 82 $\%$ of the total 21-day absorption, with the curve sloping slowly upward from that time onward at a rate of under $0,1 \%$.

- The process in Gris Barcelona sandstone was slower than in the other two materials. Absorption rose gradually in the first few hours, with the slope of the curve declining from $1,32 \%$ after sixty minutes to $0,4 \%$ after four hours, at which time absorption reached $78 \%$ of the 21 -day total. Thereafter growth was nearly flat, with slopes consistently lower than 0,1\%. Total absorption after 21 days was low $(1,83 \%)$.

\section{Comparison of suction and immersion test results}

The suction and immersion curves for each stone were compared to obtain further data for establishing the appropriate moisture content for strength testing. Although the measurements were taken at different times, the values could be combined and the two curves represented on the same graph.

The Juneda and Parisina sandstone graphs for the first 180 minutes proved to be complementary, for the absorption values at the respective singular points (full suction moistening of the top side and abrupt change in the slope of the immersion curve) concurred (Figures 4 and 5). These points can be identified with the time when the secondary pore network becomes waterclogged. Thereafter absorption progresses very slowly, as water penetrates the smallest capillaries at a nearly asymptotic rate.

In the Juneda sandstone, which had a very high absorption rate in the first phase, the secondary network filled up in ten minutes in the suction test. While in the immersion test the first measurement was taken after $60 \mathrm{~min}$ utes as specified in the standard, supplementary readings taken at shorter times showed that the secondary network clogged after five minutes under these conditions. 


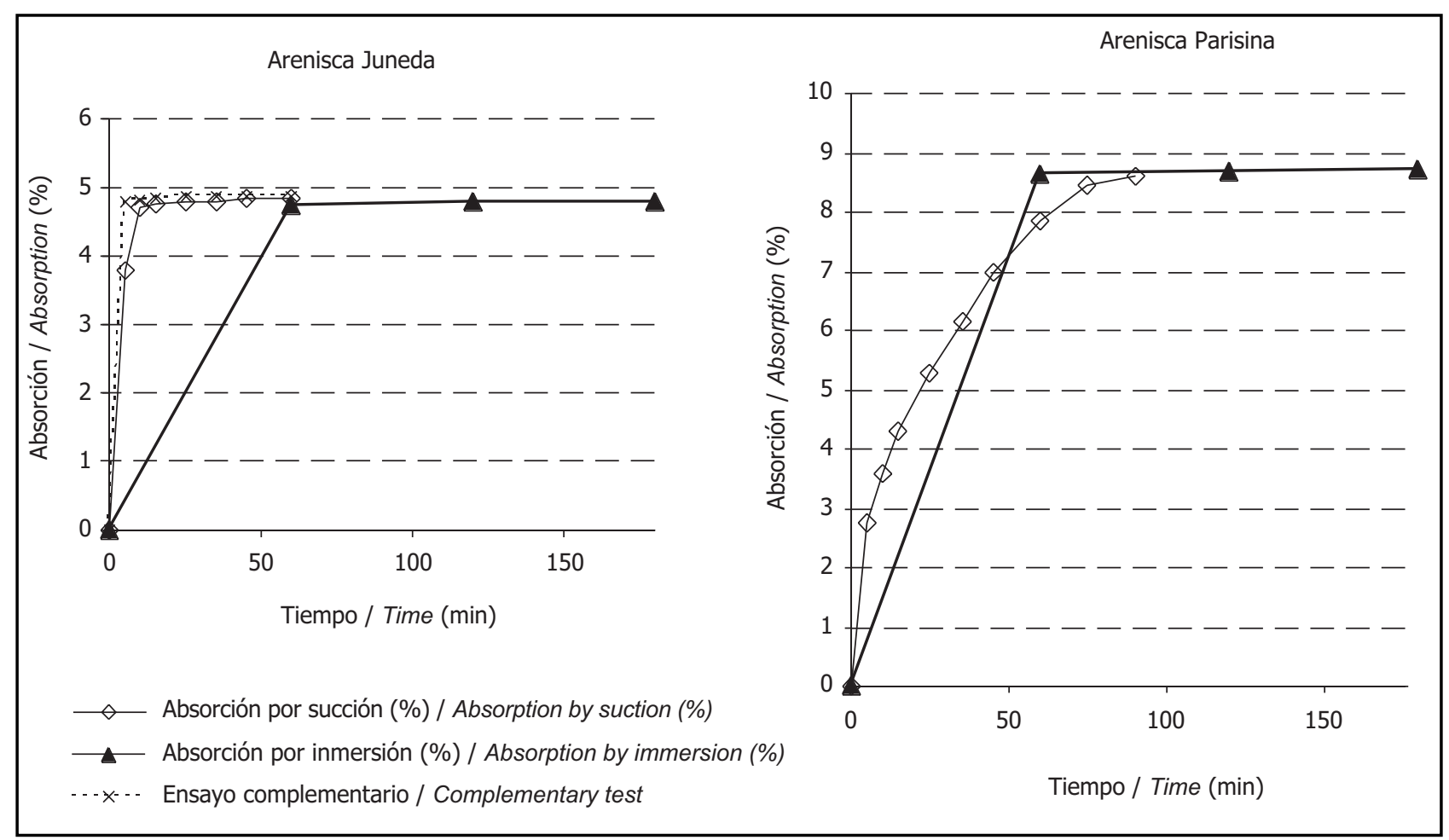

Figuras 4 y 5 . Absorción por succión e inmersión de las areniscas Juneda y Parisina.

Figures 4 and 5. Absorption by suction and by immersion of the Juneda and Parisina sandstones.

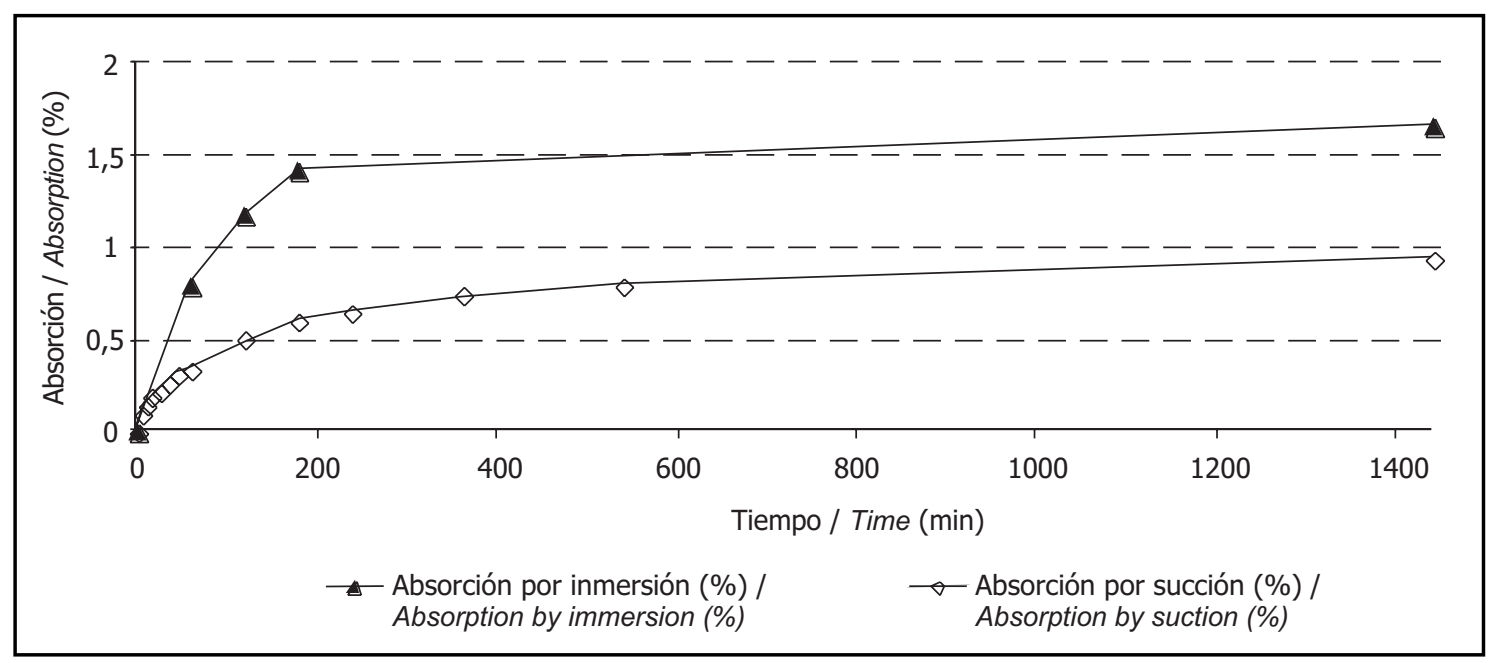

Figura 6. Absorción por succión e inmersión en la Arenisca Gris Barcelona.

Figure 6. Absorption by suction and by immersion of the Gris Barcelona sandstone.

En la arenisca Parisina las curvas no encajan hasta después de la primera medición del ensayo a inmersión, ya que colmatar la red porosa secundaria por succión (total humectación de la cara superior), requiere más tiempo que por inmersión.

El caso de la arenisca Gris Barcelona es completamente diferente. En ella el proceso de absorción es muy lento. La Figura 6 muestra las curvas correspondientes a 24
In Parisina sandstone the curves matched only after the first immersion measurement, because it took longer than 60 minutes for the secondary network to fill up (total top side moistening).

In Gris Barcelona sandstone, with a very slow absorption rate, the pattern was completely different. Figure 6 shows the curves for the first 24 hours. In the immersion 
horas de ensayo. Por inmersión, al haber un contacto perimetral bajo presión con el agua, ésta penetra hasta el núcleo de la probeta rellenando la red porosa más accesible en tres horas. Sin embargo, por succión el agua no es capaz de atravesar la probeta, por lo que los valores de absorción se mantienen siempre por debajo de los del ensayo a inmersión.

\section{Ensayo de adsorción de vapor de agua en cámara húmeda}

\section{Consideraciones previas}

Aunque los ensayos anteriores representan una acción directa del agua sobre las placas, que da lugar a contenidos de humedad altos y significativos, vamos a completar el estudio comprobando cómo se comportan las piedras ante una humedad ambiental alta (en cámara húmeda: $95 \% \mathrm{HR}$ y $22^{\circ} \mathrm{C}$ ) y baja (conservación en laboratorio: $28 \% \mathrm{HR}$ y $20^{\circ} \mathrm{C}$ ).

\section{Resultado del ensayo}

En la Tabla 3 se comparan los valores obtenidos a 7 días en las dos condiciones de humedad. En la Tabla 4 y la Figura 7 se presentan los resultados del ensayo en cámara húmeda a 7 días: test, which involved perimetric contact under pressure, the water penetrated the core of the specimen, filling the most accessible part of the pore network in three hours. With suction alone, however, it was unable to advance across the specimen and as a result these values were consistently lower than the immersion data.

\section{Water vapour absorption in a humidity chamber}

\section{Prior considerations}

Although the preceding tests represented direct water action on the panels, giving rise to high and significant moisture content values, the study was completed with a survey of stone behaviour in high (in a humidity chamber, with $95 \% \mathrm{RH}$ and $22{ }^{\circ} \mathrm{C}$ ) and low (laboratory, 28 $\% H R$ and $20^{\circ} \mathrm{C}$ ) humidity environments.

\section{Test results}

The seven-day values obtained are compared in Table 3. The seven-day humidity chamber findings are given in Table 4 and Figure 7.

Tabla 3 / Table 3

Adsorción de vapor a 7 días en laboratorio y cámara húmeda. Steam absorption after 7 days in the laboratory and in a moisture chamber.

\begin{tabular}{|c|c|c|c|}
\hline \multirow{2}{*}{$\begin{array}{c}\text { Condiciones ambientales / } \\
\text { (Envirommental conditions) }\end{array}$} & \multicolumn{3}{|c|}{ Adsorción a 7 días en \% / Absorption after 7 days (\%) } \\
\cline { 2 - 4 } & Gris Barcelona & Juneda & Parisina \\
\hline $28 \% \mathrm{HR}$ y $22^{\circ} \mathrm{C}$ & 0,033 & 0,016 & 0,151 \\
\hline $95 \% \mathrm{HR}$ y $20^{\circ} \mathrm{C}$ & 0,142 & 0,082 & 0,329 \\
\hline
\end{tabular}

Tabla 4 / Table 4

Adsorción de vapor de agua en cámara húmeda de las tres areniscas. Steam absorption in a moisture chamber of the three sandstones.

\begin{tabular}{|c|c|c|c|}
\hline \multirow{2}{*}{$\begin{array}{c}\text { Tiempo / } \\
\text { (Time) }\end{array}$} & \multicolumn{3}{|c|}{$\begin{array}{c}\text { Adsorción de vapor en cámara húmeda (\%) } \\
\text { Absorption in a damp chamber (\%) }\end{array}$} \\
\cline { 2 - 4 } & Gris Barcelona & Juneda & Parisina \\
\hline Minutos / minutes & \multicolumn{4}{|c|}{} \\
\hline 0 & 0 & 0 & 0 \\
\hline 60 & 0,038 & 0,034 & 0,165 \\
\hline 120 & 0,040 & 0,041 & 0,182 \\
\hline 180 & 0,043 & 0,054 & 0,194 \\
\hline Horas / hours & 0,089 & 0,073 & 0,309 \\
\hline 24 & 0,142 & 0,082 & 0,329 \\
\hline Días / days & \multicolumn{3}{|l}{} \\
\hline 7 & \multicolumn{4}{|l}{} \\
\hline
\end{tabular}




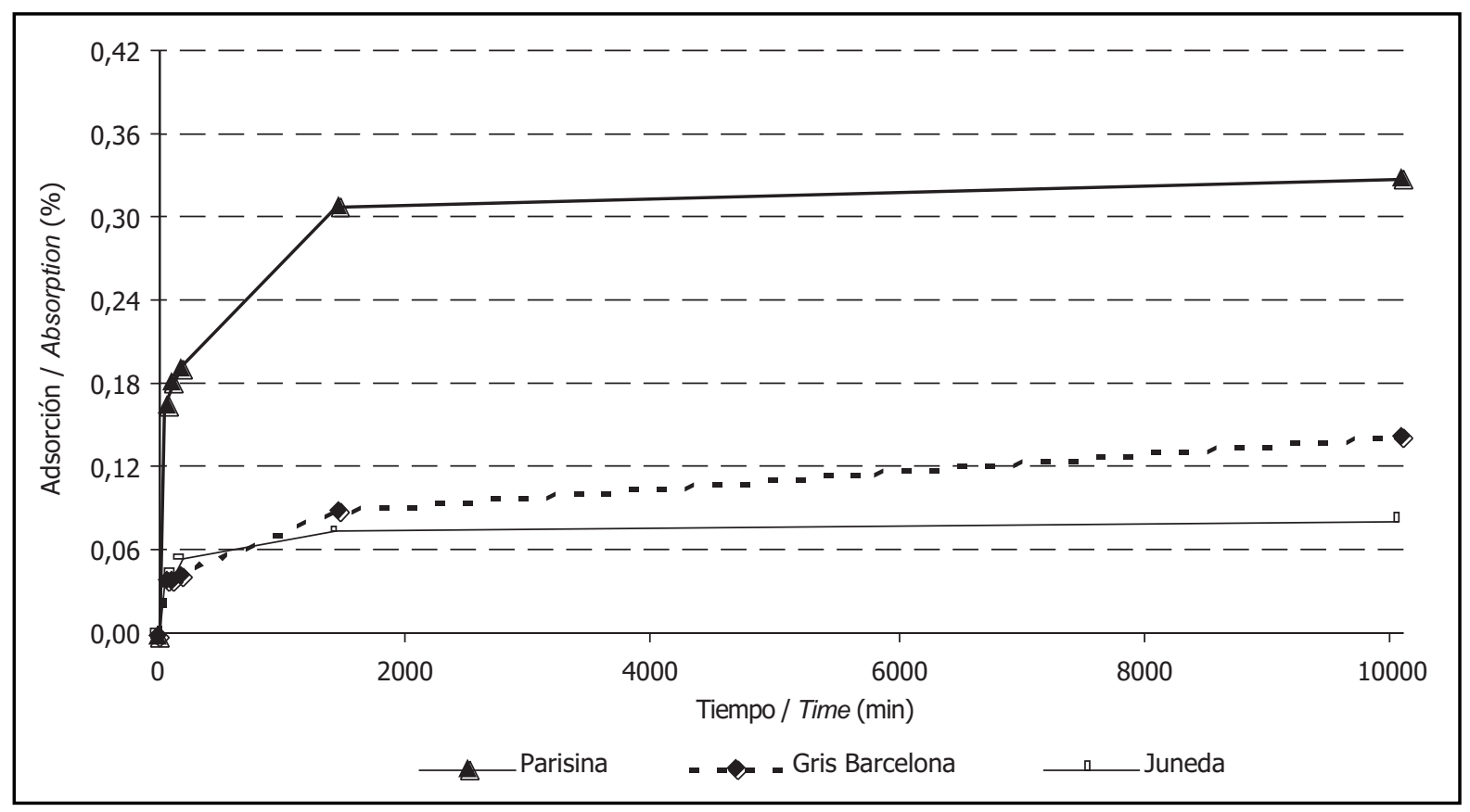

Figura 7. Adsorción media de vapor de agua en cámara húmeda de las tres piedras. Figure 7. Average absorption of water steam in a damp chamber.

- La adsorción de vapor de agua de la arenisca Parisina en condiciones de baja humedad relativa es pequeña (0,151\% a 7 días), pero en cámara húmeda es más del doble (0,329\%). Como se puede ver en la gráfica del ensayo en cámara húmeda, las ganancias se producen principalmente durante las primeras 24 horas progresando luego muy lentamente.

- En la arenisca Juneda, la adsorción para bajas humedades relativas es tan pequeña $(0,016 \%$ a 7 días $)$ que prácticamente puede considerarse que la piedra permanece seca en esas condiciones. En cámara húmeda la absorción es 5 veces superior (0,082\%), pero sigue siendo muy pequeña. A partir de las primeras 24 horas, la curva sigue un crecimiento casi asintótico con ganancias de humedad a 7 días, inferiores al 0,01\%.

- La arenisca Gris Barcelona también presenta baja adsorción en condiciones de baja humedad relativa (0,033\% a 7 días), pero en cámara húmeda este valor se cuadriplica $(0,142 \%)$, presentando además un crecimiento continuado ascendente, tal y como puede verse en la gráfica. Este comportamiento suele indicar que, una vez que se produce la adsorción de vapor en los poros, tiene lugar una progresiva condensación en la superficie de los mismos.

\section{Conclusiones sobre el comportamiento frente al agua de las tres piedras}

Para completar el estudio se han determinado la densidad aparente y la porosidad abierta de cada piedra, tomando como referencia la norma UNE-EN 1936 (8).
- The low water vapour adsorption (0,151 \% after seven days) recorded for Parisina sandstone under low relative humidity conditions doubled in the specimens stored in the humidity chamber (0,329\%). As the humidity chamber graph shows, the gain took place primarily in the first 24 hours, progressing very slowly thereafter.

- Low humidity adsorption in Juneda sandstone was so low (0,016 \% after seven days) that the stone could be regarded to remain practically dry under such conditions. While humidity chamber absorption was five times higher $(0,082 \%)$, it was still very low. After the first 24 hours, the curve rose nearly asymptotically, with seven-day moisture gains of under 0,01\%.

- Gris Barcelona sandstone also exhibited low adsorption in low relative humidity $(0,033 \%$ after seven days), but this value rose four-fold (to $0,142 \%$ ) in the humidity chamber and continued to rise, as the graph shows. Such behaviour is usually an indication of the progressive condensation of the water vapour on pore surfaces after adsorption.

\section{Conclusions on stone behaviour when exposed to water}

The study also included the determination of each stone's bulk density and open porosity as described in UNE-EN standard 1936 (8). The measures obtained were 
A las medias obtenidas se les ha aplicado la función de distribución de Student (9), para obtener resultados con una fiabilidad el $95 \%$. Los valores obtenidos se resumen en la Tabla 5. subjected to Student's t-test (9) to obtain results at a $95 \%$ confidence level. The values obtained are summarized in Table 5.

Tabla 5 / Table 5

Adsorción de vapor a 7 días en laboratorio y cámara húmeda. Steam absorption after 7 days in the laboratory and in a moisture chamber.

\begin{tabular}{|c|c|c|c|}
\hline Fiabilidad del 95\% / (95\% confidence interval) & Gris Barcelona & Juneda & Parisina \\
\hline Densidad aparente $\left(\mathrm{kg} / \mathrm{m}^{3}\right) /$ Apparent density $\left(\mathrm{kg} / \mathrm{m}^{3}\right)$ & $2526,60 \pm 29,77$ & $2233,30 \pm 12,92$ & $1931,90 \pm 29,91$ \\
\hline Porosidad abierta $(\%) /$ Open porosity $(\%)$ & $4,60 \pm 0,87$ & $12,91 \pm 0,16$ & $19,90 \pm 1,70$ \\
\hline
\end{tabular}

Por último se ha realizado la observación, bajo lupa binocular, de secciones pulidas de las tres piedras. Utilizando una luz rasante, se han podido observar las cavidades de la red porosa secundaria, lo que ha aportado datos de interés para explicar el comportamiento claramente diferente de las tres piedras (Figuras 8 a 10. Como referencia, se incluye una regla graduada cuyas divisiones corresponden a milímetros).

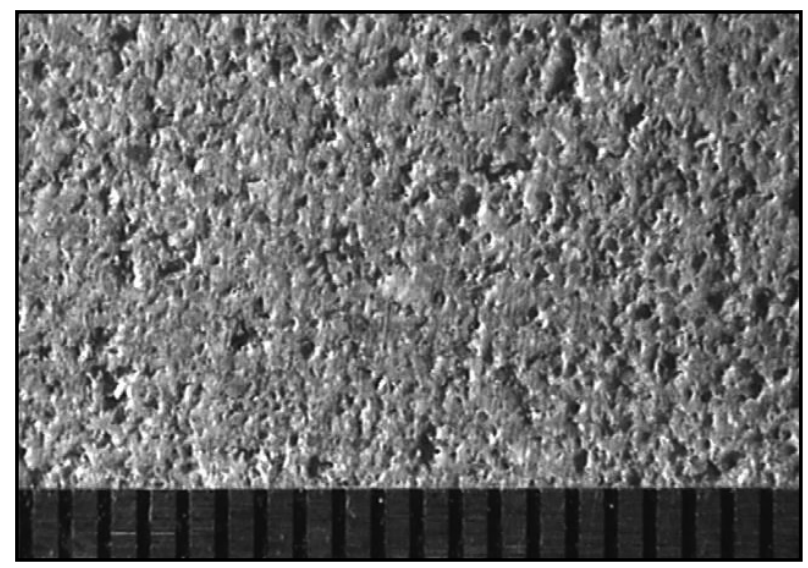

Figura 8. Arenisca Parisina. Figure 8. Parisina sandstone.
Lastly, polished sections of the three stones were observed under a binocular microscope. When viewed with sidelight, the secondary pore network vugs afforded further insight into the clearly differentiated behaviour of the three stones (Figures 8-10). (The divisions on the ruler given at the bottom for reference represent millimetres.)

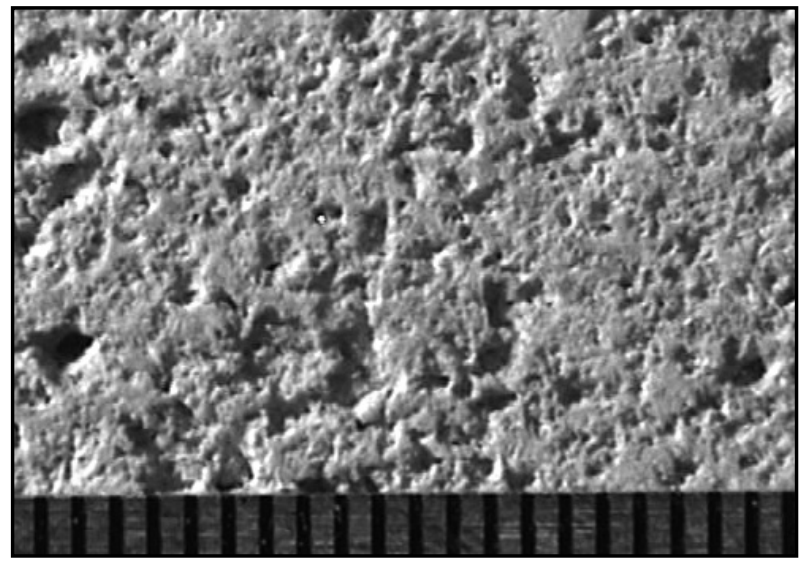

Figura 9. Arenisca Juneda. Figure 9. Juneda sandstone.

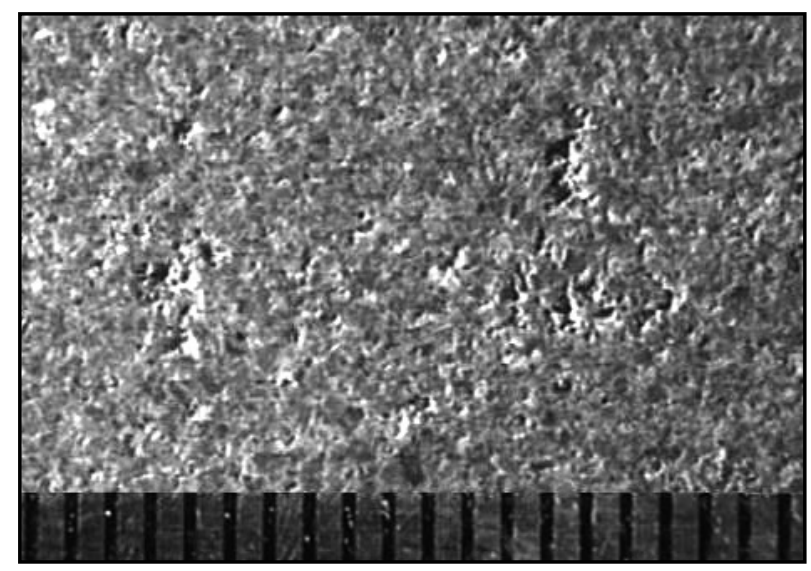

Figura 10. Arenisca Gris Barcelona.

Figure 10. Gris Barcelona sandstone. 
Como resumen de todo el estudio realizado podemos sacar las siguientes conclusiones:

- La arenisca Gris Barcelona es la más compacta de las tres rocas con una porosidad accesible baja. Ello se corresponde con que sea la de menor absorción por inmersión y con que, por succión, el agua no sea capaz de atravesar la probeta tras 24 horas de ensayo.

Aunque es difícil encontrar explicaciones simples al comportamiento de los materiales de red porosa compleja, sí se sabe que la penetración de agua, tanto por succión como bajo presión por inmersión, será menor en una red fina, ramificada y tortuosa, con poros de paredes rugosas, en la que se produzcan pérdidas por rozamiento y resistencias aisladas importantes (6). Tal es el caso de esta piedra. La observación de la Figura 10 muestra una baja presencia de cavidades, irregularmente distribuidas, por lo que la porosidad se debe fundamentalmente a red primaria de capilares de pequeño diámetro de la sustancia cementante.

La adsorción de vapor de agua es también baja pero la gráfica muestra un continuo crecimiento, lo que se correspondería también con la teoría de red capilar fina y tortuosa. En ese tipo de redes se produce una adsorción gradual, con penetración del vapor en los poros y progresiva condensación en la superficie de los mismos (10).

- La arenisca Juneda es la que presenta valores intermedios de densidad y porosidad. En consonancia presenta valores de absorción intermedios, siendo su succión muy rápida.

La mayor absorción puede relacionarse con un mayor tamaño de poro. La Figura 9 nos permite apreciar una alta presencia de cavidades de tamaño bastante regular y uniformemente repartidas. Ello indica que el agua penetra al principio muy rápidamente a través de la red secundaria de cavidades (rama inicial de las gráficas de absorción por succión e inmersión), progresando luego lentamente a través de la red primaria de poros (rama de progresión "cuasi" asintótica de las gráficas).

La adsorción de vapor de agua es muy baja, incluso menor que la de la arenisca Gris Barcelona que tiene menor porosidad abierta. Ello indica que una vez producida la difusión gaseosa de vapor en los poros no se produce condensación en su superficie, como ocurría en la arenisca Gris Barcelona, lo que se suele corresponder con poros de mayor tamaño.

- La arenisca Parisina es la de menor densidad aparente y mayor porosidad accesible, presentando una absorción elevada, tanto por inmersión como por succión. Este comportamiento se corresponde con la presencia en su red porosa de un gran número de cavidades, que pueden verse incluso a simple vista. En la Figura 8 se observa una presencia de cavidades abundante con una distribución muy irregular.

Sin embargo, a pesar de presentar mayor succión que la arenisca Juneda, en ella el proceso es más
The following conclusions were drawn from the above findings:

- Gris Barcelona sandstone is the most compact of the threes stones, with a low porosity accessible to water. This is consistent with the fact that it had the lowest immersion-mediated absorption values and that in the suction test the water was unable to advance across the specimen, even after 24 hours. While simple explanations can seldom be provided for the behaviour of materials with complex pore networks, water uptake, be it by suction or immersion, is known to be slower in a finely branched, intricate network with rough-sided pores, where friction and significant isolated resistance lead to head loss (6). This stone can be so characterized. Figure 10 shows that the vugs are scant and irregularly distributed. Consequently, porosity is due essentially to the primary network of small capillaries in the cement matrix.

The graph shows that water vapour adsorption was low but continuous, which would also be consistent with the theory of a fine, intricate network, where adsorption is gradual, with vapour penetration in the pores followed by condensation on their surface (10).

- Juneda sandstone exhibited intermediate density and porosity values. Concomitantly, intermediate absorption values were found for this stone, although suction took place very rapidly.

Its greater absorption may be related to a larger pore size. Figure 9 shows that its vugs are large and uniformly distributed, with a fairly regular shape. This is an indication that water penetrates the secondary network of vugs very rapidly (initial segment on the suction and immersion curves) and subsequently progresses across the primary pore network very slowly ("quasi"-asymptotic segment on the curves).

Water vapour adsorption was very low, even lower than in Gris Barcelona sandstone whose open porosity is smaller. The inference is that once the vapour reached the pores, it did not condense on their surface as in Gris Barcelona. Such behaviour is generally associated with larger pores.

- Parisina sandstone had the lowest bulk density and highest porosity accessible to water, along with high immersion- and suction-mediated absorption. This behaviour is consistent with the presence of the large number of vugs in its network, which are clearly visible even to the naked eye and irregularly distributed, as Figure 8 shows.

And yet, while suction was greater than in Juneda sandstone, the absorption rate was slower. 
lento. Ello podría deberse a que se precisa más tiempo para llenar la red secundaria de cavidades, debido al gran tamaño de éstas.

La adsorción de vapor de agua es alta y progresa rápidamente en los primeros instantes, pero se ralentiza a partir de las primeras 24 horas. Ello parece indicar que, tras la difusión gaseosa de vapor de agua en los poros, no se produce condensación en la superficie de los mismos.

\section{DETERMINACIÓN DEL CONTENIDO DE HUMEDAD DE REFERENCIA PARA LA REALIZACIÓN DE LOS ENSAYOS DE RESISTENCIA}

Teniendo en cuenta la forma constructiva de las fachadas que estamos analizando, que permiten la ventilación por la cara posterior, y, a la vista del resultado de los ensayos, consideramos que:

- En las areniscas Juneda y Parisina con lluvias persistentes, el agua puede atravesar la piedra, pero es difícil que se produzca una combinación de lluvia y viento que dé lugar a la saturación, habida cuenta de que, una vez colmatada la red porosa secundaria, la absorción progresa muy lentamente. Tras 24 horas de inmersión los contenidos de humedad medidos son sólo ligeramente superiores a los de los hitos de las curvas (total humectación de cara superior en ensayo a succión y cambio brusco de pendiente en curva del ensayo a inmersión). Por ello vamos a tomar el valor de succión del instante en el que la cara opuesta al agua queda totalmente humectada como valor de referencia para realizar los ensayos de comprobación de resistencias.

- En la arenisca Gris Barcelona, excepto en situaciones climatológicas muy extremas, con lluvias abundantes y continuadas y vientos fuertes y persistentes, en una fachada ventilada por su cara posterior lo más probable es que se dé el caso de que parte del espesor de la placa esté húmedo y el resto seco. Ello constituiría una situación desfavorable cuando, ante acciones mecánicas, la humedad afecte a la zona sometida a tracción.

Por ello vamos a determinar la resistencia a flexión con probetas sometidas a succión, hasta empapar aproximadamente la mitad de su espesor, ensayándolas de modo que la zona húmeda sea la sometida a tracción.

- En todo caso, si se fuesen a utilizar las piedras en una ubicación en la que pudiesen producirse situaciones climatológicas extremas, deberían hacerse ensayos específicos que representen esas condiciones, para determinar el contenido de humedad más adecuado (3).
This might be because it took longer to fill the secondary network, due to the large size of the vugs.

Water vapour adsorption was high and progressed swiftly in the first few minutes, but slowed after 24 hours. This would appear to indicate that once the water vapour reached the pores, it did not condense on their surface.

\section{DETERMINATION OF THE STANDARD MOISTURE CONTENT FOR STRENGTH TEST PURPOSES}

Inasmuch as the façades analyzed here are built to provide for ventilation on the inner side and in light of the results of the tests, the following conclusions were drawn:

- In the event of persistent rain, water may penetrate across Juneda and Parisina sandstone, but rain-driven water would hardly lead to saturation, for once the secondary pore network is soaked, absorption advances very slowly. After 24 hours of immersion, the moisture content measured was only slightly higher than the singular points on the curves (total moistening in the suction test and abrupt change in the slope of the curve in the immersion test).

Consequently, the suction value upon total moistening of the side opposite the source of water was adopted as the reference value for performing strength tests.

- In the Gris Barcelona sandstone, except in very extreme climatological conditions, with steady, copious rain and strong and persistent wind, stone cladding on ventilated façades will very likely be dry on one side and wet on the other. This would be a drawback in the event of mechanical action in which the wet area is subjected to tensile stress.

Consequently, flexural strength was determined on specimens suction-soaked to approximately one half of their thickness, which were tested ensuring that the tensile forces were applied to the wet areas.

- In any event, when stone is to be used at sites subject to extreme weather conditions, specific tests reproducing these conditions should be conducted to determine the most appropriate moisture content for these intents and purposes (3). 


\section{COMPORTAMIENTO A FLEXIÓN DE LAS PIEDRAS ANALIZADAS}

\section{Consideraciones previas}

Cuando se va a utilizar una piedra en una fachada trasventilada hay dos ensayos que deben realizarse para, a partir de sus resultados, establecer las dimensiones de la placa y número y tipo de fijaciones: determinación de la resistencia al anclaje y resistencia a flexión (1-2). Para diseñar la fachada es preciso tener en cuenta ambos resultados. Sin embargo, considerando únicamente la resistencia a flexión, podemos establecer el espesor de la placa en función de las otras dimensiones. Ello nos permitirá comparar las tres piedras y verificar la influencia del contenido de humedad en el dimensionado de las placas.

Por esa razón hemos centrado esta parte del estudio en determinar la variación de la resistencia a flexión con el contenido de humedad. Se ha seguido la norma UNE-EN 13161 (1) utilizando series de 10 probetas de $240 \mathrm{~mm}$ de largo y sección de 50x40 mm. Las probetas se han cortado como se cortan las placas en taller, por "aserrado al hilo", ensayando la piedra por aplicación de la fuerza en la cara habitualmente sometida a carga.

Se han usado probetas secas y húmedas. Las probetas secas, siguiendo los criterios de UNE-EN 13161 (1), se han desecado en estufa, estabilizándolas en laboratorio durante 24 horas. Las probetas húmedas, siguiendo los criterios del apartado anterior, se han sometido a succión hasta la total humectación de la cara superior en el caso de las areniscas Juneda y Parisina. La arenisca Gris Barcelona se ha sometido a succión hasta que el agua ha alcanzado entre $1 / 2$ y $2 / 3$ de la altura de las probetas, lo que se considera representativo de la absorción a que se puede llegar en una fachada trasventilada en condiciones climatológicas adversas. Las probetas se han ensayado de modo que la cara húmeda sea la traccionada (Figura 11).

\section{FLEXURAL STRENGTH OF THE STONE ANALYZED}

\section{Prior considerations}

Two tests should be conducted to establish panel dimensions and number of attachments for ventilated façades with stone cladding: dowel hole failure load and flexural strength (1-2). Both parameters must be borne in mind in façade design. Nonetheless, cladding thickness can be established based on flexural strength alone, and varied depending on the other dimensions. This approach can be used to compare the three stones and verify the effect of moisture content on panel thickness.

This part of the study, then, focused on the variations in flexural strength with moisture content. Further to UNE-EN standard 13161 (1) specifications, series of ten 240-mm long specimens were prepared, with 50x40-cm cross-sections. The specimens were ripsawn (i.e., sawn with the vein), as they are in the shop, and tested by applying the force on the side that is usually loaded.

Both dry and wet specimens were used. The dry specimens were kiln-dried and allowed to stabilize in the laboratory for 24 hours, as specified in UNE-EN 13161 (1). In accordance with the above standard, Juneda and Parisina sandstone specimens were wetted by suction until the entire top side was soaked. Gris Barcelona sandstone was moistened by suction until the water reached from $1 / 2$ to $2 / 3$ of the specimen height, which was regarded to be representative of the absorption attainable in a ventilated façade under adverse weather conditions. In these tests, tensile stress was applied to the wet side of the specimen (Figure 11).

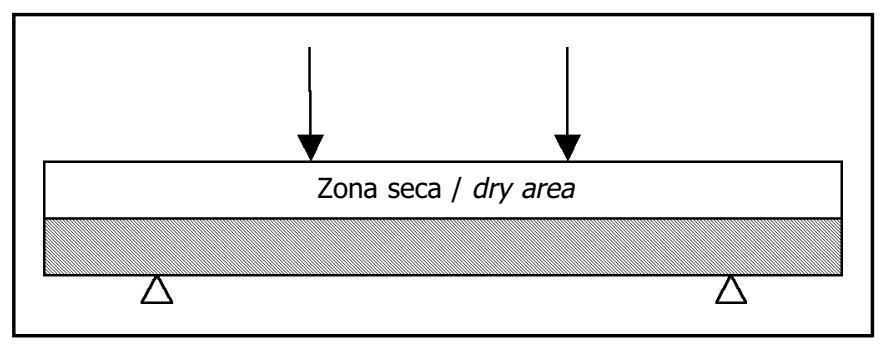

Figura 11. Ensayo a flexión de las probetas húmedas de arenisca Gris Barcelona. Figure 11. Test of the wet specimens of the Gris Barcelona sandstone. 
De acuerdo con la norma de referencia UNE-EN 13161:2002 (1), se ha determinado el valor inferior esperado de la resistencia que corresponde al cuantil del $5 \%$ de una distribución normal logarítmica para un nivel de confianza del $75 \%$.

\section{Resultado de los ensayos}

Los resultados se pueden ver en la Tabla 6 y en la Figura 12. En la figura se ha representado la resistencia media a flexión de las tres piedras en estado seco y húmedo. Sobrepuesto en blanco aparece el valor inferior esperado.
As stipulated in UNE-EN standard 13161:2002 (1), the lowest expected strength was determined as the $5 \%$ quantile in a normal logarithmic distribution, assuming a confidence level of $75 \%$ (1).

\section{Test results}

The results are given in Table 6 and Figure 12. The figure shows the mean flexural strength for the three stones, dry and wet. The white insert represents the lowest expected value.

Tabla 6 / Table 6

Resistencia a flexión de las tres areniscas en estado seco y húmedo. Flexural strength of the three sandstones by using dry and wet specimens.

\begin{tabular}{|c|c|c|c|c|c|c|c|c|c|}
\hline & \multicolumn{3}{|c|}{ Gris Barcelona } & \multicolumn{3}{|c|}{ Juneda } & \multicolumn{3}{|c|}{ Parisina } \\
\hline & $\begin{array}{c}\text { Cont. de } \\
\text { humedad (\%) / } \\
\text { Moisture } \\
\text { content (\%) }\end{array}$ & $\begin{array}{c}\mathbf{R f} \\
(\mathrm{MPa})\end{array}$ & $\begin{array}{l}\text { Rf min } \\
\text { (MPa) }\end{array}$ & $\begin{array}{c}\text { Cont. de } \\
\text { humedad (\%) / } \\
\text { Moisture } \\
\text { content (\%) }\end{array}$ & $\begin{array}{c}\mathbf{R f} \\
(\mathrm{MPa})\end{array}$ & $\begin{array}{l}\text { Rf min } \\
\text { (MPa) }\end{array}$ & $\begin{array}{c}\text { Cont. de } \\
\text { humedad (\%) / } \\
\text { Moisture } \\
\text { content (\%) }\end{array}$ & $\begin{array}{c}\mathbf{R f} \\
(\mathrm{MPa})\end{array}$ & $\begin{array}{l}\text { Rf min } \\
\text { (MPa) }\end{array}$ \\
\hline $\begin{array}{l}\text { Prob. secas / } \\
\text { Dry specimens }\end{array}$ & 0,07 & 10,45 & 7,82 & 0,05 & 7,51 & 5,87 & 0,14 & 3,12 & 0,76 \\
\hline $\begin{array}{l}\text { Prob. húmedas / } \\
\text { Wet specimens }\end{array}$ & 1,31 & 6,47 & 3,65 & 4,09 & 4,25 & 2,92 & 8,54 & 1,11 & 0,09 \\
\hline
\end{tabular}

$\mathrm{R}_{\mathrm{f}}=$ Resistencia media a flexión (Mean Value of the flexural strength) / $R_{f}$ min. Valor inferior esperado (Lower expected value).

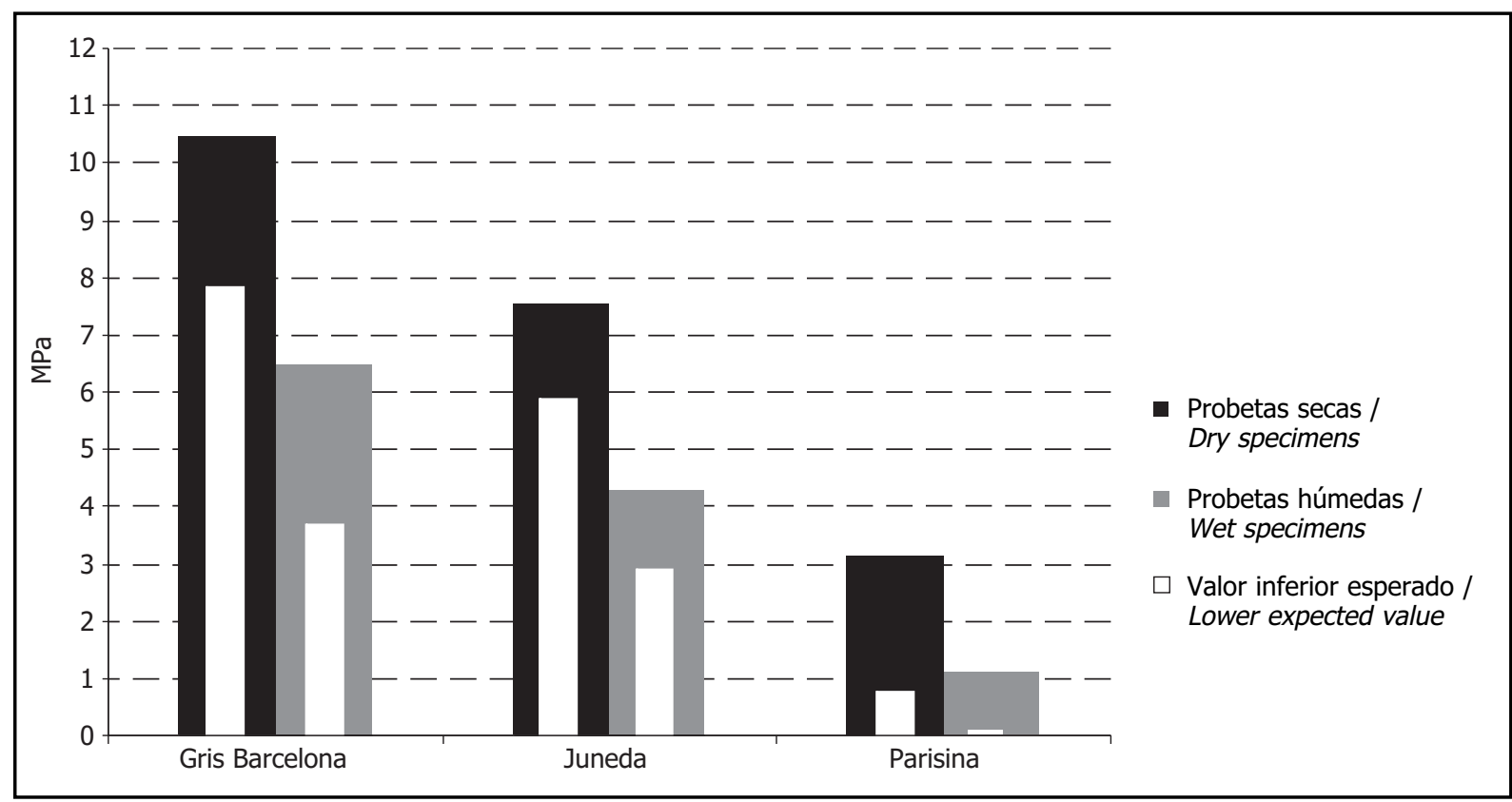

Figura 12. Resistencia a flexión de las tres piedras en estado seco y húmedo. Figure 12. Flexural strength of the three stones (dry and wet specimens). 
Las tres piedras experimentan pérdidas importantes de resistencia cuando se humedecen. En las areniscas Gris Barcelona y Juneda estas pérdidas están en torno al $40 \%$, mientras que en la Parisina son de un $64 \%$. Hay que tener en cuenta que esta última presenta además una resistencia en seco baja, perdiendo en húmedo la capacidad para ser utilizada en fachadas trasventiladas.

\section{Aplicación de los resultados obtenidos al dimensionado de placas}

Para ilustrar lo que supone la pérdida de resistencia y cómo influye en el diseño de fachadas trasventiladas vamos a determinar los espesores de placa en función de la resistencia a flexión obtenida. Para ello, vamos a tomar como ejemplo una fijación con pasadores verticales tal y como se muestra en la Figura 13.
Strength declined substantially in the three stones when wet. This decline was on the order of $40 \%$ in Gris Barcelona and Juneda, while in Parisina strength dropped by $64 \%$. Since this last stone also had a low dry strength, when wet it proved to be unsuitable for ventilated façades.

\section{Application of the results to panel dimensioning}

To illustrate the relevance of strength loss and how it affects ventilated façade design, panel thicknesses were determined on the basis of the flexural strength values found. Vertical dowel-type attachments such as shown in Figure 13 were assumed in the example.

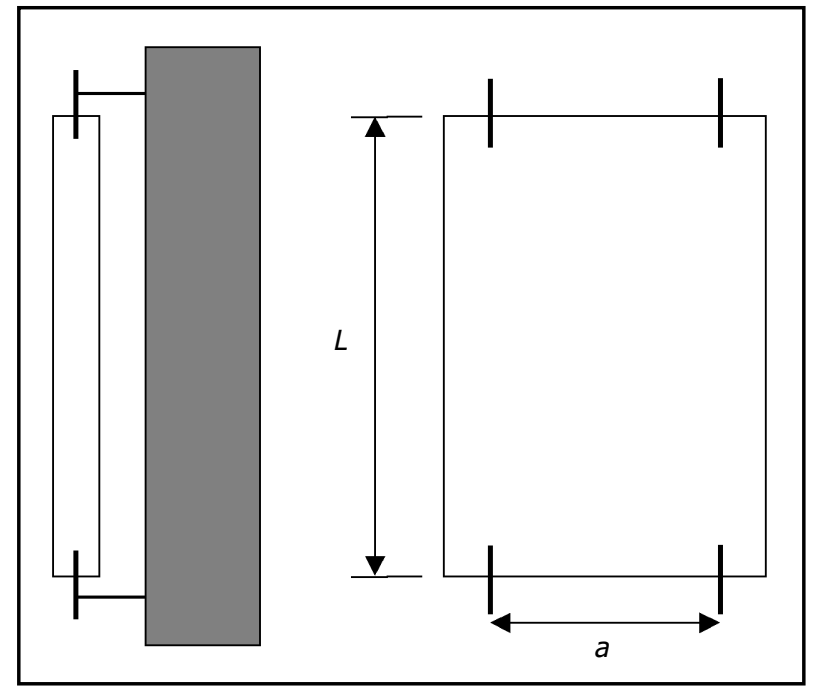

Figura 13. Ensayo a flexión de las probetas húmedas de arenisca Gris Barcelona. Figure 13. Test of the wet specimens of the Gris Barcelona sandstone.

Para encontrar la fórmula adecuada que nos permita relacionar el espesor de la placa con la resistencia a flexión de la piedra debemos tener en cuenta que:

1. La sujeción de las placas en 4 puntos aislados podría producir un trabajo bidireccional a flexión. Sin embargo, teniendo en cuenta que habitualmente el tamaño de placas es tal que la dirección de flexión $L$, es claramente superior a la $a, y$ que, en un material tan frágil como la piedra, es difícil esperar un comportamiento de este tipo, debemos aceptar que la placa flecha perpendicularmente a los bordes fijados.

2. De forma simplificada podemos considerar que la placa está sujeta de forma continua en los dos bordes
The considerations borne in mind to find the formula that correctly related cladding thickness to stone flexural strength included:

1. Attaching the panels at four separate points may lead to bi-directional bending. Nonetheless, given that panel size is usually such that flexural direction $L$ is clearly larger than a and that such behaviour is unlikely in material as brittle as stone, panel deflection must be assumed to be perpendicular to the attached edges.

2. To simplify calculations, the panel may be regarded to be attached along the entire length of the two 
donde se realizan los anclajes. Existen estudios que demuestran que el error que se comete con ello es pequeño y los espesores que se obtienen son similares a los obtenidos considerando fijaciones aisladas (11).

3. El grado de empotramiento en el anclaje va a ser pequeño y dependerá de la penetración del perno en el taladro y de la existencia o no de casquillos de ajuste. Del lado de la seguridad optaremos por considerar empotramiento cero, es decir, apoyo simple.

4. Con estos planteamientos la comprobación más desfavorable se produce en la sección central de la placa sometida a momento máximo y cortante nulo.

De acuerdo con todo ello podemos usar la siguiente fórmula (12), para determinar el espesor de placa: [1] anchored edges. Studies by TJS Yates et al. (11) showed that the error committed with this simplification is small and the thickness values found are similar to the findings for point anchoraging.

3. Anchor moment fixity is small and depends on the penetration depth of the bolt in the drill hole and the use or otherwise of plastic pegs. To be on the safe side, zero fixity, i.e., a simple support, was assumed.

4 On these grounds the highest stress would be borne by the central section of the panel subjected to maximum moment and nil shear.

In light of the foregoing, the following formula (12) can be used to determine panel thickness: [1]

$$
e=\sqrt{\frac{750 \cdot P \cdot L^{2} \cdot F}{R_{f}}}
$$

En donde $\boldsymbol{e}$ es el espesor en $\mathrm{mm} ., \boldsymbol{P}$ la presión de viento característica en $\mathrm{kN} / \mathrm{m}^{2}, L$ la longitud de flexión en metros y $\boldsymbol{R} \boldsymbol{f}$ la resistencia a flexión de la piedra en $\mathrm{MPa}$. $F$ es un coeficiente de seguridad que, de acuerdo con el manual ASTM MNL 21 (13), puede tomarse $\boldsymbol{F}=6$.

La Tabla 7 muestra los espesores obtenidos en función de $\boldsymbol{L}$ y $\boldsymbol{P}$. Se ha considerado para ello el valor inferior esperado de la resistencia, ya que en las tres piedras la dispersión de resultados fue grande, con desviaciones típicas altas. El ejemplo más notable de ello es el de la arenisca Parisina, debido a su estructura poco homogénea: distribución del material detrítico no uniforme, granulometría de partículas heterogénea y presencia de cavidades, inclusiones y microfracturas que se pueden observar a simple vista. En varios casos se ha comprobado cómo, en esta piedra, la rotura por flexión se produce coincidiendo con defectos evidentes de este tipo. En la Figura 14 se puede ver una fotografía obtenida a través de la lupa binocular, con luz cenital, de una muestra en la que se aprecia la presencia de una fractura. where $\boldsymbol{e}$ is the thickness in $\mathrm{mm}, \boldsymbol{P}$ the standard wind pressure in $\mathrm{kN} / \mathrm{m}^{2}, \boldsymbol{L}$ the flexural length in metres and $\boldsymbol{R} f$ the flexural strength of the stone in MPa. $\boldsymbol{F}$ is a safety factor which, according to ASTM manual MNL 21 (13), can be taken to be equal to 6 .

Table 7 shows the thickness values obtained depending on $L$ and $P$. In light of the wide dispersion of the results and high standard deviations found for all three stones, the lowest expected strength was substituted in the formula. This dispersion was particularly evident in Parisina sandstone, due to its scant homogeneity: non-uniform distribution of detrital matter and particle size and the presence of vugs, inclusions and microfissures, visible to the naked eye. In several trials, flexural failure in Parisina stone concurred with obvious flaws of this type. Figure 14, obtained with a binocular microscope and overhead light, shows a fissure in a Parisina sandstone sample.

Tabla 7 / Table 7

Ejemplo. Espesores de placa para una $L=1,2 \mathrm{~m}$ y una presión de viento $P=1 \mathrm{kN} / \mathrm{m}^{2}$. Example. Thickness of the slabs being $L=1,2 \mathrm{~m}$ and the wind pressure $P=1 \mathrm{kN} / \mathrm{m}^{2}$.

\begin{tabular}{|c|c|c|c|c|c|c|c|c|c|}
\hline & \multicolumn{3}{|c|}{ Gris Barcelona } & \multicolumn{3}{|c|}{ Juneda } & \multicolumn{3}{c|}{ Parisina } \\
\cline { 2 - 10 } & $\begin{array}{c}R_{f} \min \\
\mathbf{( M p a )}\end{array}$ & $\mathbf{e}$ & $e \mathbf{( m m . )}$ & $\begin{array}{c}R_{f} \min \\
(\mathbf{M p a})\end{array}$ & $\mathbf{e}$ & $e(\mathbf{m m})$ & $\begin{array}{c}R_{f} \min \\
(\mathbf{M p a})\end{array}$ & $e$ & $e(\mathbf{m m})$ \\
\hline $\begin{array}{c}\text { Probetas secas / } \\
\text { Dry specimens }\end{array}$ & 7,82 & 24,0 L.P1/2 & 28,79 & 5,87 & 27,7 L.P1/2 & 33,23 & 0,76 & 77,0 L.P1/2 & 92,34 \\
\hline $\begin{array}{c}\text { Probetas húmedas } / \\
\text { Wet specimens }\end{array}$ & 3,65 & 35,1 L.P1/2 & 42,13 & 2,92 & 39,3 L.P1/2 & 47,11 & 0,09 & 223,6 L.P1/2 & 268,33 \\
\hline
\end{tabular}




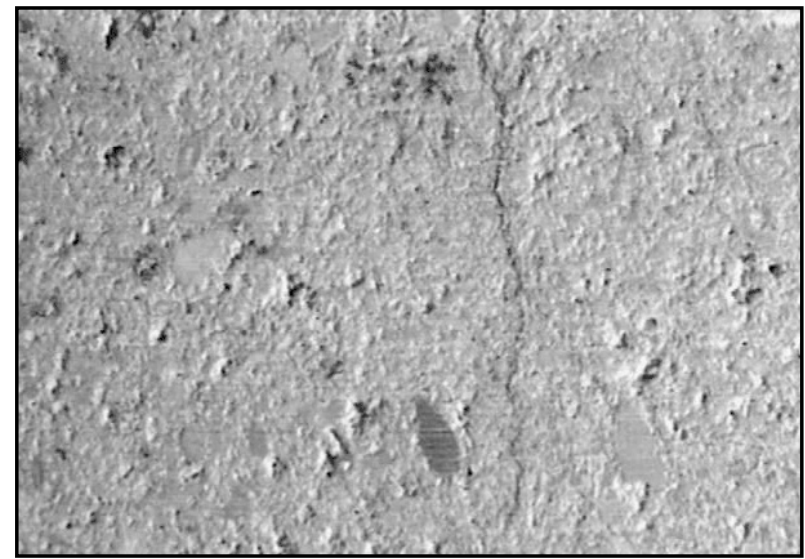

Figura 14. Ejemplo de fisura en arenisca Parisina.

Figure 14. Example of a fissure in the Parisina sandstone.

De todas formas para manejar datos más claros hemos dado valores a $\boldsymbol{L}$ y $\boldsymbol{P}$ para obtener $\boldsymbol{e}$ en $\mathrm{mm}$ (Tabla 7). Se han elegido valores habituales en fachadas trasventiladas. En cualquier caso no es más que un ejemplo para mostrar cómo afecta el contenido de humedad al dimensionado de las placas. Los valores elegidos son $L=\mathbf{1 , 2}$ $\mathbf{m}$ y $P=1 \mathrm{kN} / \mathrm{m}^{2}$.

La primera consideración que debe hacerse es que la arenisca Parisina no es una piedra adecuada para la realización de fachadas trasventiladas, ni siquiera impermeabilizándola, ya que, incluso en estado seco, sus resistencias son tan bajas que obligarían a considerar placas de pequeña longitud o espesores excesivos, o a buscar soluciones constructivas con mayor número de anclajes. Todas ellas son soluciones poco aceptables desde el punto de vista económico.

Las otras dos piedras pueden usarse en fachadas trasventiladas, siendo las dimensiones de las placas y diseño de anclajes dependientes, tanto de la resistencia de la piedra como de la presión de viento máxima esperable sobre la fachada.

\section{CONCLUSIONES}

De acuerdo con los resultados del estudio es evidente que la desconsideración del contenido de humedad en piedras porosas conduce a un dimensionado poco seguro de las placas. En el ejemplo, para las areniscas Juneda y Gris Barcelona, con la resistencia en seco obtenemos espesores en torno a $30 \mathrm{~mm}$, mientras que si tuviésemos en cuenta la resistencia en húmedo tendríamos que llegar a espesores entre 40 y $50 \mathrm{~mm}$, o bien, reconsiderar el diseño de la fachada variando la longitud de la placa o la posición, tipo y número de anclajes.
For greater clarity, $\boldsymbol{L}$ and $\boldsymbol{P}$ were assigned values that would yield e in $\mathrm{mm}$ (see Table 7). Values normally used in ventilated façades were chosen. In any event this is a mere example to show how moisture content can affect panel dimensioning. The values chosen were: $L=1,2 \mathrm{~m}$ y $P=1 \mathrm{kN} / \mathrm{m}^{2}$.

The first deduction is that Parisina sandstone is not apt for ventilated façades, even when water-proofed, for its dry strength is so low that the panels would have to be inordinately long and thick or fastened with a larger number of anchors. None of these solutions is economically acceptable.

The other two stones are suitable for use on ventilated façades. Panel dimensions and anchor design depend on both stone strength and the maximum wind pressure to which the façade is expected to be exposed.

\section{CONCLUSIONS}

The above findings clearly show that failure to consider moisture content in porous stone leads to unsafe panel dimensioning. In the example, the dry strength-based thicknesses obtained for Juneda and Gris Barcelona stone were on the order of $30 \mathrm{~mm}$, whereas the wet strength values would either call for thicknesses of from 40 to $50 \mathrm{~mm}$ or necessitate façade redesign, varying panel length or position or the type and number of anchors. 
Por ello, en estos casos, se debe tener en cuenta este factor a la hora de realizar los ensayos de resistencia, tanto a flexión como a arrancamiento en el anclaje. Sin embargo, consideramos que no deben utilizarse probetas saturadas, ya que es poco probable que las placas de una fachada trasventilada alcancen ese estado. En obras concretas, el contenido de humedad adecuado debe elegirse tras un estudio detallado del comportamiento de la piedra frente al agua, teniendo en cuenta las condiciones meteorológicas de la zona en la que se ubique el edificio. Por el contrario, cuando lo que se quiere es aportar datos generales de una piedra, que permitan al proyectista decidir sobre su uso en fachadas trasventiladas, se puede simular su comportamiento frente al agua de lluvia mediante un ensayo a succión y elegir un contenido de humedad representativo analizando los puntos singulares de la curva de absorción.

En definitiva, antes de usar una piedra en una fachada trasventilada debería contarse con información suficiente sobre su comportamiento frente al agua y sobre la influencia del contenido de humedad en la resistencia. La Norma en vigor, en la que se establecen los requisitos que deben cumplir las placas de revestimiento de fachadas y a través de la cual se realiza el marcado CE del producto, es la UNE-EN 1469:2005 (14). Dicha Norma se limita, en lo referente a absorción y resistencia, a establecer los ensayos que deben realizarse, que son los ya comentados (1-2, 4,5). En ellos no se estudia de forma comparada el comportamiento frente al agua de la piedra ni se tiene en cuenta el contenido de humedad para la determinación de resistencias.

En el caso de rocas porosas, creemos, no obstante, que debería poderse contar con una información más amplia, parte de la cual es la que proponemos. La utilidad de la misma se demuestra a través del ejemplo desarrollado.

Esta propuesta constituye una primera aproximación al problema. En casos concretos pueden realizarse estudios más complejos, teniendo en cuenta datos climatológicos específicos y realizando ensayos por rociado que simulen los grados de intensidad y dirección de la lluvia. También sería interesante valorar factores, como el tiempo de secado, comparando la cinética de los procesos de absorción y desorción. Estudios realizados a este respecto en areniscas (15) han detectado comportamientos diferentes en función de las características petrográficas y texturales de las mismas.
For these reasons, account must be taken of moisture content when conducting both flexural strength and dowel hole failure tests. Wholly soaked panels need not be tested, however, for it is unlikely that ventilated façade cladding will ever reach saturation. In specific projects, the appropriate moisture content should be determined after conducting a detailed survey of stone behaviour when exposed to water, simulating the weather conditions prevailing at the building site. On the contrary, when general information is needed on a stone to enable the design engineer to decide on its usability in ventilated façades, its behaviour when exposed to rainwater can be simulated in suction tests and the representative moisture content chosen by analyzing the singular points on the absorption curve.

In short, before using a stone on a ventilated façade, sufficient information should be gathered on its behaviour when exposed to water and the effect of moisture content on its strength. The standard in effect, which establishes the requirements to be met by façade cladding and under which the CE mark is awarded, is UNE-EN 1469:2005 (14). As far as absorption and strength are concerned, that standard simply stipulates the tests that must be conducted, which are set out in references $(1-2,4,5)$. These standards do not call for comparing stone behaviour when exposed to water nor do they take account of moisture content when determining strength.

In the case of porous rock, however, the present article advocates the need for fuller information, as discussed above. The utility of such information is shown in the example described.

This proposal constitutes a first approach to the problem. More complex studies can be conducted in particular cases, tailored to specific climatological data and conducting spray tests that simulate different degrees of rain intensity and direction, as well as other variables such as drying time. Other factors might also be assessed, such as drying time, comparing absorption and desorption kinetics. Studies conducted on sandstone (15) identified different behaviour in this respect, depending on the petrographic and textural characteristics of the material.

\section{BIBLIOGRAFÍA / BIBLIOGRAPHY}

(1) UNE-EN 13161:2002: "Métodos de ensayo para piedra natural. Determinación de la resistencia a flexión a momento constante".

(2) UNE-EN 13364:2002: "Métodos de ensayo para piedra natural. Determinación de la carga de rotura para anclajes".

(3) Vielba Cuerpo, C.; Hernández Olivares, F.: "Ensayos de caracterización del comportamiento frente al agua de la piedra natural". Mater. Construcc., vol. 52, no 267 (2002), pp. 43-54. 
(4) UNE-EN 1925:1999: "Métodos de ensayo para piedra natural. Determinación del coeficiente de absorción de agua por capilaridad".

(5) UNE-EN 13755:2002: "Métodos de ensayo para piedra natural. Determinación de la absorción de agua a presión atmosférica".

(6) Barenblatt, G.I. et al: Theory of fluid flows through natural rocks, Kublic Academic Publishers (1990).

(7) Esbert Alemany, R.M.: "Alteración de rocas graníticas utilizadas en edificación". Mater. Construcc., vol. 57, no 288 (2007), pp 77-89.

(8) UNE-EN 1936:2007: "Métodos de ensayo para piedra natural. Determinación de la densidad real y aparente y de la porosidad abierta y total".

(9) Turner, J. C.: Matemática moderna aplicada. Probabilidad, estadística e investigación operativa, Alianza Universal, Madrid (1986).

(10) Bear, J.: Dynamics of fluids in porous media, American Elsevier Publishing Company, Inc. (1972).

(11) Yates, T.J.S.; Matthews, S.L.; Chakrabatrti, B.: "External cladding: how to determine the thickness of natural stone panels". BRE Information Paper $7 / 98$ (abril 1998).

(12) Cerdeño del Castillo, F. J.; López González-Mesones, F. et al: La piedra natural en la arquitectura contemporánea. AITEMIN-Centro Tecnológico, Toledo (2007).

(13) Lewis, M. D.: "Modern Stone Cladding: Design and Installation of Exterior Dimension Stone Systems", Manual Series ASTM MNL 21. Philadelphia (1995).

(14) UNE-EN 1469:2005: "Piedra Natural. Placas para revestimientos murales. Requisitos".

(15) Buj, O.; Gisbert, J.: "Caracterización petrofísica de tres variedades comerciales de areniscas miocenas del valle del Ebro". Mater. Construcc., vol. 57, no 287 (2007), pp. 63-74. 